\title{
Calcium isotope fractionation in alpine plants
}

\section{Journal Article}

\section{Author(s):}

Hindshaw, Ruth S.; Reynolds, Ben C.; Wiederhold, Jan Georg; Kiczka, Mirjam; Kretzschmar, Ruben (1); Bourdon, Bernard

Publication date:

2013-03

Permanent link:

https://doi.org/10.3929/ethz-b-000064850

\section{Rights / license:}

In Copyright - Non-Commercial Use Permitted

\section{Originally published in:}

Biogeochemistry 112(1-3), https://doi.org/10.1007/s10533-012-9732-1 


\title{
Calcium isotope fractionation in alpine plants
}

\author{
R. S. Hindshaw $\cdot$ B. C. Reynolds \\ J. G. Wiederhold $\cdot$ M. Kiczka $\cdot$ R. Kretzschmar • \\ B. Bourdon
}

Received: 12 May 2011/Accepted: 15 March 2012/Published online: 19 April 2012

(C) Springer Science+Business Media B.V. 2012

\begin{abstract}
In order to develop Ca isotopes as a tracer for biogeochemical $\mathrm{Ca}$ cycling in terrestrial environments and for $\mathrm{Ca}$ utilisation in plants, stable calcium isotope ratios were measured in various species of alpine plants, including woody species, grasses and herbs. Analysis of plant parts (root, stem, leaf and flower samples) provided information on $\mathrm{Ca}$ isotope fractionation within plants and seasonal sampling of leaves revealed temporal variation in leaf $\mathrm{Ca}$ isotopic composition. There was significant $\mathrm{Ca}$ isotope fractionation between soil and root tissue $\Delta^{44 / 42}$ $\mathrm{Ca}_{\text {root-soil }} \approx-0.40 \%$ in all investigated species, whereas $\mathrm{Ca}$ isotope fractionation between roots and leaves was species dependent. Samples of leaf tissue collected throughout the growing season also highlighted species differences: Ca isotope ratios increased with leaf age in woody species but remained constant in herbs and grasses. The $\mathrm{Ca}$ isotope fractionation between roots and soils can be explained by a preferential binding of light $\mathrm{Ca}$ isotopes to root
\end{abstract}

R. S. Hindshaw $(\varangle) \cdot$ B. C. Reynolds ·

J. G. Wiederhold · M. Kiczka · B. Bourdon

Institute of Geochemistry and Petrology, ETH Zurich,

Clausiusstrasse 25, 8092 Zurich, Switzerland

e-mail: ruth.hindshaw@ngu.no; hindshaw@erdw.ethz.ch

R. S. Hindshaw · J. G. Wiederhold · M. Kiczka ·

R. Kretzschmar

Institute of Biogeochemistry and Pollutant Dynamics,

ETH Zurich, CHN, Universitätstrasse 16,

8092 Zurich, Switzerland adsorption sites. The observed differences in whole plant $\mathrm{Ca}$ isotopic compositions both within and between species may be attributed to several potential factors including root cation exchange capacity, the presence of a woody stem, the presence of $\mathrm{Ca}$ oxalate, and the levels of mycorrhizal infection. Thus, the impact of plants on the $\mathrm{Ca}$ biogeochemical cycle in soils, and ultimately the $\mathrm{Ca}$ isotope signature of the weathering flux from terrestrial environments, will depend on the species present and the stage of vegetation succession.

Keywords Calcium - Stable isotope fractionation · Glacier forefield · Alpine plants

\section{Introduction}

The presence of vegetation has a major impact on the biogeochemical cycles of many elements, through uptake, re-cycling and the acceleration of weathering rates (Drever 1994; Bormann et al. 1998). As one of the essential plant macronutrients, calcium has been particularly intensively studied (Likens et al. 1998; McLaughlin and Wimmer 1999; White and Broadley 2003).

Calcium plays an essential role in plant growth and development. Calcium is used for signalling (in response to stimuli, changes in intracellular $\mathrm{Ca}$ concentrations induce physiological changes), 
maintaining membrane integrity, stomatal regulation, enzyme activation and for the structural integrity of the plant, where it is a major component of cell walls (Marschner 1995; McLaughlin and Wimmer 1999).

Uptake of Ca occurs by mass flow of $\mathrm{Ca}$, driven by transpiration, into the vicinity of cells walls, where it is adsorbed, typically by the carboxyl groups of cell wall pectins (Haynes 1980). Within the roots, a small fraction of Ca flow is symplastic (through cells) as it is required within cells for signalling, but the majority of flow is non-metabolic (Drew and Biddulph 1971) and apoplastic (between cells) (White and Broadley 2003). The vast majority of $\mathrm{Ca}$ transport in the plant is through the xylem and the accumulation of $\mathrm{Ca}$ is determined by the transpiration rate and the root CEC, both of which are species dependent (White and Broadley 2003). Plant leaves are a sink for $\mathrm{Ca}$ and unlike most other plant nutrients, $\mathrm{Ca}$ is not retranslocated later in the growing season. Calcium is the least mobile of the plant macronutrients in phloem tissue and plants lose $\mathrm{Ca}$ through leaf fall and leaching (Marschner 1995; McLaughlin and Wimmer 1999).

Calcium uptake by vegetation has previously been investigated using a combination of elemental ratios (typically $\mathrm{Ca} / \mathrm{Sr}$ and $\mathrm{Ca} / \mathrm{Ba}$ ) and radiogenic $\mathrm{Sr}$ (Bailey et al. 1996; Poszwa et al. 2000; Bullen and Bailey 2005; Dasch et al. 2006; Blum et al. 2008; Drouet and Herbauts 2008; Pett-Ridge et al. 2009). The results from these studies show that, in addition to mineral weathering, atmospheric deposition is an important source of Ca for plants (Bullen and Bailey 2005; Blum et al. 2008; Pett-Ridge et al. 2009). In densely vegetated environments or in highly weathered soils, the majority of Ca released when a plant dies is taken up by other plants (biologically recycled) and only a small fraction is exported to streams (Bullen and Bailey 2005; Blum et al. 2008). Although radiogenic $\mathrm{Sr}$ can in theory act as an analogue for $\mathrm{Ca}$ (Capo et al. 1998), the sources of $\mathrm{Sr}$ and $\mathrm{Ca}$ are not exactly the same and the use of elemental ratios is complicated by varying discrimination factors within the plant (Poszwa et al. 2000; Drouet and Herbauts 2008).

Radioactive ${ }^{45} \mathrm{Ca}$ has a long history of use in plant nutrition studies (Drew and Biddulph 1971; Ferguson and Bollard 1976). However, it is only recently that stable $\mathrm{Ca}$ isotopes have been utilised in vegetation studies (e.g. Holmden and Bélanger 2010). Stable isotopes have the potential to refine our understanding of the biological cycling of elements and act as tracers for the impact of vegetation in biogeochemical cycles. Within the biogeochemical $\mathrm{Ca}$ cycle, uptake by vegetation is one of the few processes known to induce large stable $\mathrm{Ca}$ isotope fractionation in nature (Wiegand et al. 2005; Page et al. 2008; Cenki-Tok et al. 2009; Holmden and Bélanger 2010; Hindshaw et al. 2011). Calcium isotopes thus have the potential to trace $\mathrm{Ca}$ cycling within ecosystems, but first, the exact processes inducing $\mathrm{Ca}$ isotope fractionation between plant tissues and during uptake need to be investigated.

Previous studies of $\mathrm{Ca}$ isotope fractionation in vegetation have concentrated on tree species within forested ecosystems. These studies have clearly shown that within-plant $\mathrm{Ca}$ isotope fractionation occurs, with root samples exhibiting the lightest $\mathrm{Ca}$ isotopic compositions in the plant (lighter than source $\mathrm{Ca}$ ) and leaves the heaviest (Wiegand et al. 2005; Page et al. 2008; Holmden and Bélanger 2010; Cenki-Tok et al. 2009). It is not clear at present what causes the large $\mathrm{Ca}$ isotope fractionation between soil and roots. Identifying the source of $\mathrm{Ca}$ is complicated in forested ecosystems due to the presence of chemically (and isotopically) distinct soil horizons and different rooting depths (Holmden and Bélanger 2010). As different plant species will have different demands for calcium (Marschner 1995) this will likely lead to species specific fractionation patterns. In order to investigate $\mathrm{Ca}$ isotope fractionation in a wider range of plant families, we analysed several species of small alpine plants. The small size of alpine plants allowed us to collect complete plant samples and obtain whole plant $\mathrm{Ca}$ isotopic compositions, in addition to those of individual tissues. In order to directly relate these results to previous work on $\mathrm{Ca}$ isotope fractionation in an alpine environment (Hindshaw et al. 2011), plant samples were taken from the same fieldsite (Damma glacier). This allowed us to also investigate the effect of soil heterogeneity and mycorrhiza on plant $\mathrm{Ca}$ isotopic compositions. The aims of the study were to investigate species differences, within plant fractionation and seasonal differences in plant $\mathrm{Ca}$ isotopic compositions.

\section{Fieldsite and methods}

All plant samples were collected from the Damma glacier forefield, which is the focus of a large 
interdisciplinary study on initial weathering, soil formation and ecosystem development (BigLink Project, Bernasconi et al. 2011). The Damma glacier fieldsite is a small $\left(10.7 \mathrm{~km}^{2}\right)$, glaciated, granitic alpine catchment which is snow covered for approximately six months of the year. Due to the retreat of the glacier, a $\sim 1.5 \mathrm{~km}$ long soil chronosequence has formed in the glacier forefield which spans approximately 150 years of soil development. The soils in the forefield were classified as Hyperskeletic Leptosols following the World Reference Base for Soil Resources (WRB 2006). In the glacier forefield area, three distinct zones of vegetation development were observed. The youngest zone (ice-free since 1992) had very little vegetation cover apart from a few pioneer plant species, e.g. Leucanthemopsis alpina. In the middle zone (exposed between 1927 and 1950) the vegetation was typified by herbs and grasses, e.g. Agrostis gigantea and Rumex scutatus. The oldest zone (exposed before the early 1900s) was dominated by woody vegetation such as Rhododendron ferrugineum. A range of different species from different plant orders were analysed in this study (Table 1).

Three sets of samples were collected from the forefield in 2008. The first set of samples consisted of tissues (root, stem, leaf and flower samples) from individual specimens of Rhododendron and Rumex to investigate within-plant $\mathrm{Ca}$ isotope fractionation. Two different specimens of Rhododendron were analysed ( $\mathrm{RhA}$ and $\mathrm{RhB}$ ), in addition to the roots of a third (RhC). The complete root systems of the Rhododendron specimens were unable to be collected due their great areal extent. RhA and $\mathrm{RhB}$ were from soil which was 75 years old, and $\mathrm{RhC}$ was from soil which was 110 years old (at the time of sampling in 2008). Three types of soil material surrounding $\mathrm{RhB}$ were analysed in order to investigate whether the immediate soil environment was influenced by the plant. The three types of soil samples were: organic soil (uppermost layer below the litter horizon), bulk soil (homogenised soil sample from 0 to $5 \mathrm{~cm}$ below the organic soil layer) and rhizosphere soil (soil which had to be shaken off plant roots). The Rumex specimen grew on soil which was approximately 10 years old and here the complete root system was obtained. The root samples of Rumex and RhC were peeled to give a stele sample (innermost part of the root) and a cortex sample (outer part of the root) (see Fig. 1a). This sample set has previously been described and analysed for iron isotopes by Kiczka et al. (2010).

The second set of samples was used to investigate seasonal variations in plant $\mathrm{Ca}$ isotopic composition. These samples were collected from a site where the soil was approximately 75 years old and consisted of leaves from Rhododendron and Oxyria, and leaves and flowers from Agrostis. Leaf samples were collected at one month intervals over the growing season. Each sample was a composite sample of leaves from several individual plants. Due to the difficulty of separating Agrostis leaves from the stem, Agrostis 'leaf' samples contain both stem and leaf tissue.

The third set of samples served to investigate if the age of the soil affected the above-ground biomass $\mathrm{Ca}$ isotopic composition. The above-ground plant parts of L. alpina, Salix $h$. and Salix $r$. were collected from soils of different ages along the chronosequence. The infection of plant roots by mycorrhizal fungi may alter the plant $\mathrm{Ca}$ isotopic composition. In order to investigate this, the percentage of roots infected by mycorrhizal fungi was estimated microscopically

Table 1 List of plant species analysed in this study

\begin{tabular}{llllc}
\hline Full species name & Abbreviated name used in text & Family & Type & Samples analysed \\
\cline { 3 - 5 } & & & PT & L \\
\hline Rhododendron ferrugineum & Rhododendron & Ericaceae & Woody & $\times$ \\
Salix helvetica & Salix $h$. & Salicaceae & Woody & $\times$ \\
Salix retusa & Salix $r$. & Salicaceae & Woody & $\times$ \\
Oxyria digyna & Oxyria & Polygonaceae & Herb & $\times$ \\
Rumex scutatus & Rumex & Polygonaceae & Herb & $\times$ \\
Leucanthemopsis alpina & L. alpina & Asteraceae & Herb & \\
Agrostis sp. & Agrostis & Poaceae & Grass & \\
\hline
\end{tabular}

$P T$ different plant tissues, $L$ seasonal leaf samples, $C R$ above-ground plant samples from along the chronosequence 


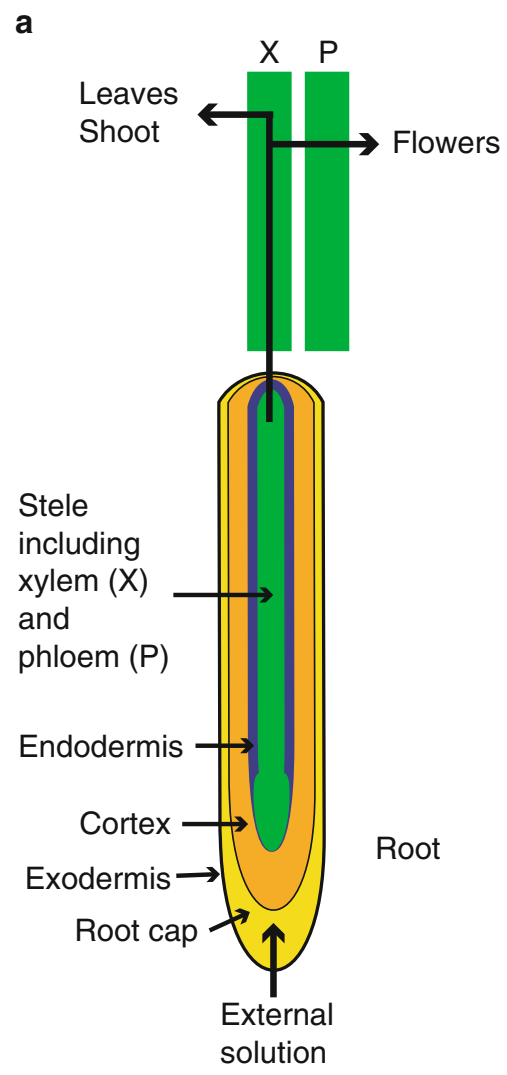

Fig. 1 a Plant uptake and movement through plant. Calcium enters the plant at the root tip and moves by apoplastic flow (see b) to the xylem which transports Ca to the rest of the plant. The majority of $\mathrm{Ca}$ uptake occurs at the root tips where the endodermis (which prevents apoplastic flow) is not yet developed. b Transport pathways. Apoplastic flow occurs within the cell walls and symplastic flow occurs within the cytoplasm. For $\mathrm{Ca}$ to enter phloem tissue it must use the symplastic pathway. Due to the toxicity of high cytoplasmic $\mathrm{Ca}$ concentrations the vast majority of $\mathrm{Ca}$ transport in the plant is

using the gridline intersection method (Giovannetti and Mosse 1980). In addition, sporocap (fruiting body) samples from two different species of mycorrhiza were sampled.

All plant samples were washed with deionized water, dried at $35^{\circ} \mathrm{C}$ and ground using either a tungsten carbide rotary disc mill or a zirconium oxide mixer mill depending on the sample size. The first and second set of samples were digested using distilled $15 \mathrm{M} \mathrm{HNO}_{3}$ and $\mathrm{H}_{2} \mathrm{O}_{2}(30 \%)$ in a microwave oven (Kiczka et al. 2010) and the third set of samples were ashed in silver crucibles at $550{ }^{\circ} \mathrm{C}$ and then dissolved in distilled $15 \mathrm{M} \mathrm{HNO}_{3}$ and $\mathrm{H}_{2} \mathrm{O}_{2}(30 \%)$. b

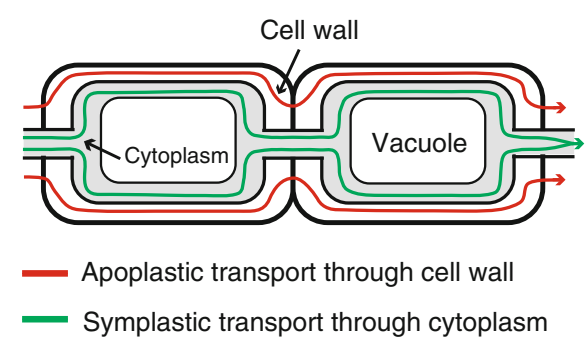

C

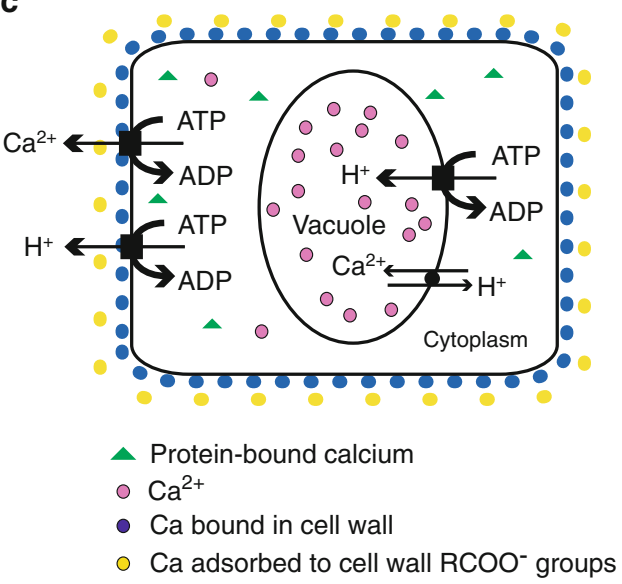

through the apoplasm. c Distribution of $\mathrm{Ca}$ in a cell and the active transport processes which may induce $\mathrm{Ca}$ isotope fractionation. The majority of $\mathrm{Ca}$ is located inside the vacuole and in the cell wall. Additional $\mathrm{Ca}$ is adsorbed onto carboxyl groups located on cell walls. In order to maintain low cytoplasmic $\mathrm{Ca}$ concentrations $\mathrm{Ca}$ ATPase and $\mathrm{Ca}^{2+} / \mathrm{H}^{+}$ antiporters move $\mathrm{Ca}$ out of the cytoplasm and into the vacuole or the apoplasm. Figures based on Marschner (1995) and Karley and White (2009)

Potential sources of $\mathrm{Ca}$ for plants have previously been described for this field site by Hindshaw et al. (2011). The $\mathrm{Ca}$ isotopic composition of porewaters, bulk soils and soil sequential extracts were measured. A five-step sequential extraction procedure was used which targeted the following pools: exchangeable, organically bound, phyllosilicates and two residual soil pools.

Elemental concentrations were analysed by inductively-coupled plasma optical emission spectrometry (ICP-OES) (Vista-MPX, Varian Inc., USA). Measured major cation concentrations of the standard NCS DC 73349 were within $20 \%$ of certified values and 
average precision for $\mathrm{Ca}^{2+}$ was $5 \%, \mathrm{Sr}^{2+} 2 \%$ and $\mathrm{Ba}^{2+} 10 \%$ (Kiczka et al. 2010, electronic annex). Aliquots of each sample, containing approximately $3 \mu \mathrm{g}$ of $\mathrm{Ca}$, were processed through a four-stage ion exchange column chemistry procedure in order to remove interfering elements prior to analysis by thermal ionisation mass spectrometry (Triton, Thermo Fischer Scientific) using a ${ }^{43} \mathrm{Ca}-{ }^{46} \mathrm{Ca}$ double-spike technique to correct for instrumental mass bias. Each sample was measured at least twice. The Ca separation and mass spectrometry procedures were identical to those described by Hindshaw et al. (2011). Calcium isotope ratios are reported in delta notation:

$$
\left.\delta^{44 / 42} \mathrm{Ca}(\%)=1000\left\{\frac{\left(\frac{{ }^{44} \mathrm{Ca}}{{ }^{42} \mathrm{Ca}}\right)_{\text {sample }}}{\left({ }^{44} \mathrm{Ca}\right.}\right)_{\text {SRM915a }}-1\right\}
$$

The external $2 \sigma_{\mathrm{SD}}$ reproducibility $(n=79)$ of NIST SRM 915 b was $0.07 \%$ and, as this was greater than internal errors, this was used as the error for all samples.

Whole plant $\mathrm{Ca}$ isotopic compositions were calculated using the following mass balance equation:

$$
\delta^{44 / 42} \mathrm{Ca}_{\text {plant }}=\frac{\sum_{i} m_{i}[\mathrm{Ca}]_{\mathrm{i}} \delta^{44 / 42} \mathrm{Ca}_{\mathrm{i}}}{\sum m_{i}[\mathrm{Ca}]_{i}}
$$

where $i$ is a plant part (root, stem, leaf, flower), $m$ is the dry mass and [Ca] is the Ca concentration. The root mass of Rhododendron was estimated to be $25 \%$ of the whole plant mass based on a study of Rhododendron arboreum (Rana et al. 1989). The Ca isotopic composition of the root cortex was not analysed but was calculated by mass balance using the following equation:

$$
\delta^{44 / 42} \mathrm{Ca}_{\text {cortex }}=\frac{\delta^{44 / 42} \mathrm{Ca}_{\mathrm{r}}[\mathrm{Ca}]_{\mathrm{r}}-\delta^{44 / 42} \mathrm{Ca}_{\mathrm{s}}[\mathrm{Ca}]_{\mathrm{s}} \mathrm{f}_{\mathrm{s}}}{[\mathrm{Ca}]_{r}-[\mathrm{Ca}]_{s} f_{s}}
$$

where $r$ is the complete root, $s$ is the stele (peeled root) and $f_{s}$ is the fraction of root mass contributed by the stele.

\section{Results}

\section{Soil pools}

In this fieldsite, soil Ca concentrations were typically around $10 \mathrm{~g} \mathrm{~kg}^{-1}$ and the average Ca isotopic composition was $0.44 \pm 0.07 \% \quad(n=49) \quad$ (Hindshaw et al. 2011). The range of soil $\mathrm{Ca}$ isotopic compositions was $0.28-0.57 \%$ and this is the range indicated in the figures. All of the soil sequential extraction steps yielded $\delta^{44 / 42} \mathrm{Ca}$ values which were within error of bulk soil values (Hindshaw et al. 2011) and the measured $\mathrm{Ca}$ isotopic compositions of porewater samples $\left(\delta^{44 / 42} \mathrm{Ca}=0.31-0.42 \%\right)$ were also within range of soil values. The lightest $\mathrm{Ca}$ isotope value measured in the soils $(0.28 \%)$ was heavier than all of the whole plant $\mathrm{Ca}$ isotopic compositions measured (Table 3). The $\delta^{44 / 42} \mathrm{Ca}$ value of the rhizosphere soil was not significantly different from the bulk or organic soil samples of the same soil age (Table 2) and this value $(0.40 \%)$ is used as the soil $\delta^{44 / 42} \mathrm{Ca}$ value in the calculation of plant-soil $\mathrm{Ca}$ isotopic differences.

Whole plant analyses

The Ca concentrations of Rumex tissues increased from root $\left(9.34 \mathrm{~g} \mathrm{~kg}^{-1}\right)$ to stem $\left(10.8 \mathrm{~g} \mathrm{~kg}^{-1}\right)$ to leaf $\left(31.4 \mathrm{~g} \mathrm{~kg}^{-1}\right)$. A similar increase in concentration was observed for the two Rhododendron specimens analysed, but the absolute concentrations were lower, for example the highest leaf Ca concentration was only $9.19 \mathrm{~g} \mathrm{~kg}^{-1}$ (Table 2). The Ca concentration of the leaves of both species was more than three times that found in the whole root. Flower tissue had higher $\mathrm{Ca}$ concentrations than stem tissue in Rhododendron, but in Rumex, flower tissue had lower Ca concentrations than both the stem and the root. Within the root, the cortex (outer root) had higher Ca concentrations than the stele (inner root) for both species. In Rumex, the cortex was seven times more concentrated in $\mathrm{Ca}$ than the stele, whereas in Rhododendron it was only twice as concentrated. The alkali earth element ratios $\mathrm{Sr} / \mathrm{Ca}$ and $\mathrm{Ba} / \mathrm{Ca}$ decreased along the transpiration stream (stele to leaf) in Rumex and the same general trend was observed in Rhododendron (stem to leaf) (Fig. 2a; Table 2).

In both species there was significant $\mathrm{Ca}$ isotope fractionation $(>0.36 \%$ o $)$ between the soil pool $\left(\delta^{44 / 42} \mathrm{Ca}=0.40 \%\right)$ and the roots (Fig. 3). Within the Rhododendron specimen $\mathrm{RhB}$ there was little isotope fractionation from root $\left(\delta^{44 / 42} \mathrm{Ca}=0.04 \%\right.$ o $)$ to stem $(0.09 \%)$ to leaf $(0.00 \%)$, the same was observed for RhA but the tissues were isotopically lighter than those of RhB (Fig. 3). The flowers of both 
Table 2 Ca concentrations, $\delta^{44 / 42} \mathrm{Ca}$ and element ratios for different plant tissues and soils

\begin{tabular}{|c|c|c|c|c|c|c|}
\hline Sample & Total weight (g) & [Ca] $(\mathrm{g} / \mathrm{kg})$ & $\mathrm{Sr} / \mathrm{Ca}(\mathrm{mmol} / \mathrm{mol})$ & $\mathrm{Ba} / \mathrm{Ca}(\mathrm{mmol} / \mathrm{mol})$ & $\begin{array}{l}\delta^{44 / 42} \mathrm{Ca} \\
2 \sigma_{\mathrm{SD}}=0.07 \%\end{array}$ & $\begin{array}{l}\triangle^{44 / 42} C a_{\text {plant-soil }}^{\mathrm{a}} \\
2 \sigma_{\mathrm{SD}}=0.10 \% \text { o }\end{array}$ \\
\hline \multicolumn{7}{|l|}{ Rhododendron A } \\
\hline Root & $9.53^{\mathrm{b}}$ & 1.59 & 1.39 & 6.09 & -0.09 & -0.49 \\
\hline Stem & 20.7 & 2.02 & 1.09 & 7.35 & -0.16 & -0.56 \\
\hline Leaf & 5.51 & 9.29 & 0.49 & 2.20 & -0.11 & -0.51 \\
\hline Flower & 2.39 & 3.63 & 0.76 & 4.61 & -0.31 & -0.71 \\
\hline \multicolumn{7}{|l|}{ Rhododendron B } \\
\hline Bulk soil & - & 10.6 & 7.23 & 17.4 & 0.38 & \\
\hline Organic soil & - & 12.2 & 6.44 & 13.1 & 0.38 & \\
\hline Rhizosphere soil & - & 8.03 & 7.52 & 28.2 & 0.40 & \\
\hline Root & $2.79^{\mathrm{b}}$ & 1.16 & 1.66 & 12.2 & 0.04 & -0.36 \\
\hline Stem & 5.36 & 2.52 & 1.41 & 13.2 & 0.09 & -0.31 \\
\hline Leaf & 2.59 & 7.14 & 0.76 & 4.43 & 0.00 & -0.40 \\
\hline Flower & 0.42 & 3.03 & 1.04 & 9.40 & -0.20 & -0.60 \\
\hline \multicolumn{7}{|l|}{ Rhododendron C } \\
\hline Whole root & - & 1.05 & 1.65 & 15.7 & 0.01 & -0.39 \\
\hline Cortex $^{c}$ & - & 1.45 & & & 0.03 & -0.37 \\
\hline Stele & - & 0.65 & 1.81 & 16.6 & -0.02 & -0.42 \\
\hline \multicolumn{7}{|l|}{ Rumex } \\
\hline Whole root & 2.53 & 9.34 & 2.16 & 1.34 & -0.11 & -0.51 \\
\hline Cortex & 0.80 & 22.4 & 2.05 & 0.48 & -0.17 & -0.57 \\
\hline Stele & 1.74 & 3.33 & 2.51 & 1.80 & 0.08 & -0.32 \\
\hline Stem & 1.99 & 10.8 & 1.76 & 1.69 & -0.05 & -0.45 \\
\hline Leaf & 1.35 & 31.4 & 0.83 & 0.83 & 0.41 & 0.01 \\
\hline Flower & 0.82 & 6.43 & 0.69 & 0.76 & 0.40 & 0.00 \\
\hline
\end{tabular}

Values in italics are calculated from mass balance equations

${ }^{\text {a }}$ Relative to rhizosphere soil $\delta^{44 / 42} \mathrm{Ca}=0.40 \%$

b Assumes roots contribute $25 \%$ to total plant mass

c Assumes the cortex and stele contribute $50 \%$ each to the root mass

Table 3 Whole plant $\delta^{44 / 42} \mathrm{Ca}$ compositions (\%o relative to soil $\left(\triangle^{44 / 42} C a_{\text {plant-soil }}\right)$ based on mass balance

\begin{tabular}{lccr}
\hline Fraction & RhA & RhB & Rumex \\
\hline Complete plant & -0.54 & -0.37 & -0.23 \\
Ste + St + L + F & - & - & -0.14 \\
St + L + F & -0.55 & -0.37 & -0.13 \\
L + F & -0.54 & -0.42 & 0.01 \\
\hline
\end{tabular}

Ste stele, $S t$ stem, $L$ leaf, $F$ flower

specimens were $0.2 \%$ lighter than the leaves. For Rumex, the $\delta^{44 / 42} \mathrm{Ca}$ value of root and stem tissue was nearly identical to that of Rhododendron but the leaves and flowers had higher $\delta^{44 / 42} \mathrm{Ca}$ values $\left(\delta^{44 / 42} \mathrm{Ca}=\right.$
$0.40 \%$ ), in the range of soil $\delta^{44 / 42} \mathrm{Ca}$ values (Fig. 3). The cortex of Rumex roots was $0.25 \%$ lighter than the stele. As the complete root system of a Rhododendron specimen could not be obtained, the fraction of root mass in the stele is not known. However, given the measured isotopic compositions and concentrations of the stele and the whole root, it was calculated using Eq. 3, that the mass fraction of stele could change from 10 to $90 \%$ and the resulting isotopic composition of the cortex $\left(\delta^{44 / 42} \mathrm{Ca}=0.01-0.05 \%\right)$ would not differ, within error, from that of the stele $\left(\delta^{44 / 42} \mathrm{Ca}=-0.02 \%\right)$.

Whole plant $\mathrm{Ca}$ isotopic compositions, calculated using Eq. 2, were $0.23-0.54 \%$ lighter than soil 

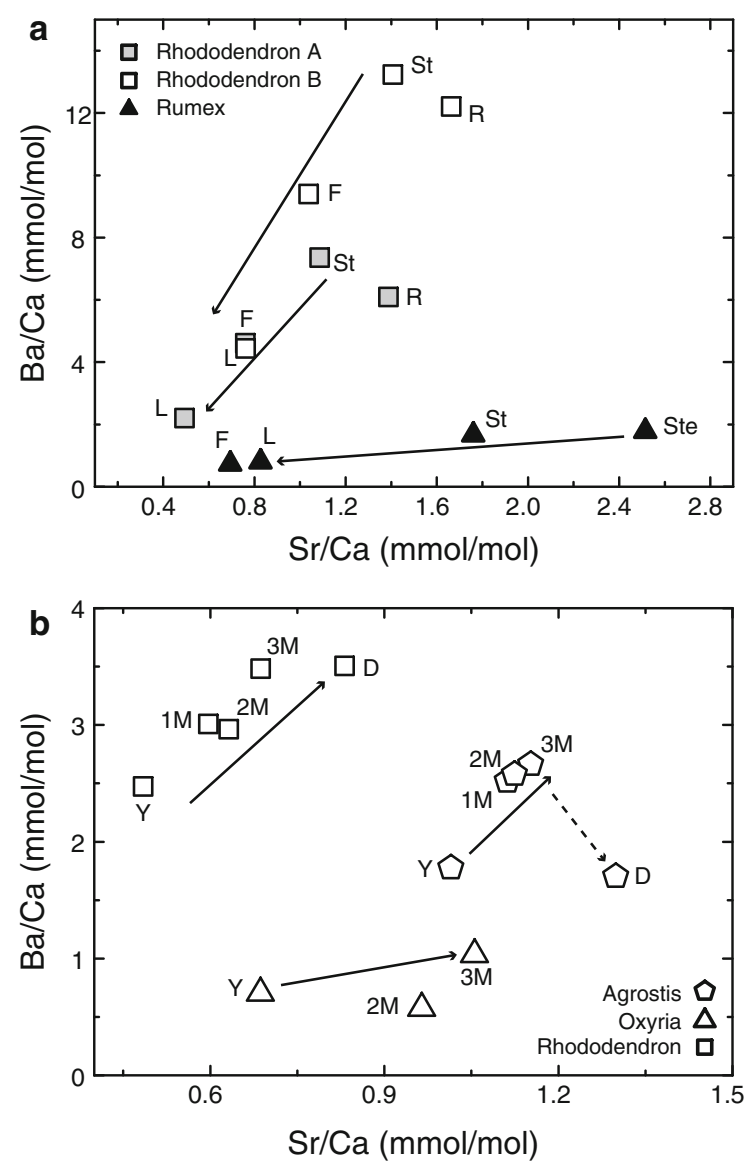

Fig. 2 Change in $\mathrm{Ba} / \mathrm{Ca}$ and $\mathrm{Sr} / \mathrm{Ca}$ ratios a along the transpiration stream and $\mathbf{b}$ over the growing season in the leaves. Arrows highlight the direction of change. In (b) the dotted arrow points to a straw (dead leaf) sample which may be influenced by leaching processes and decomposition on the ground. $R$ root; $S t$ stem; $F$ flower; $L$ leaf; Ste stele; $Y$ young leaves; $1 M, 2 M$ and $3 M$ 1,2 and 3 month old leaves respectively; $D$ dead leaves

(Fig. 3), unambiguously demonstrating that the uptake of Ca from soils by plants is accompanied by an enrichment of light $\mathrm{Ca}$ isotopes. In addition to calculating the whole plant $\mathrm{Ca}$ isotopic composition, Eq. 2 was used to calculate the isotopic composition of the whole plant at each step of the transpiration stream. The results (Table 3) confirm the negligible withinplant fractionation in the Rhododendron specimens, but highlight the increase in Ca isotope ratios along the transpiration stream in Rumex.

\section{Seasonal variation}

The Ca concentration of leaves increased with age, with 3 month old leaves up to six times as concentrated

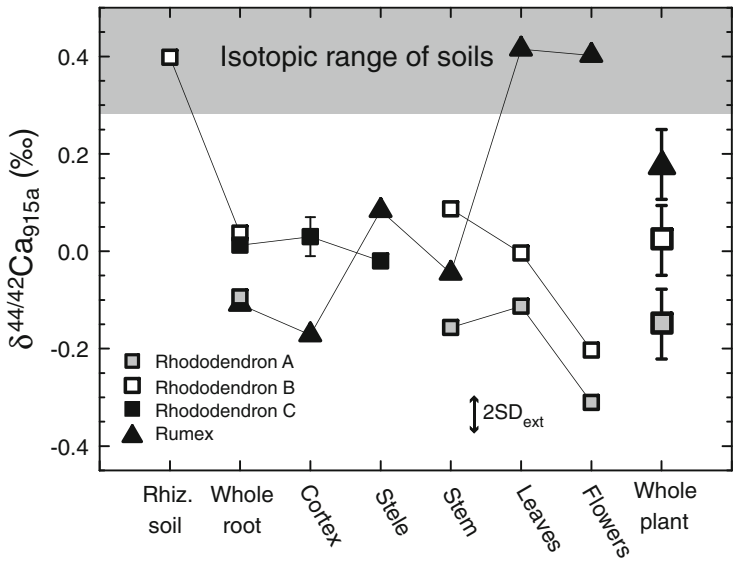

Fig. 3 Variation of $\delta^{44 / 42} \mathrm{Ca}$ between different plant tissues for two specimens of Rhododendron and one specimen of Rumex. Rhiz. soil stands for rhizosphere soil-the soil in direct contact with the plant roots. The Ca isotopic composition of the cortex is calculated using Eq. 3. The range in Rhododendron cortex $\delta^{44 / 42} \mathrm{Ca}$ is the range obtained when the mass fraction of the cortex is varied from 10 to $90 \%$. The error in whole plant isotopic compositions is $0.14 \%$. For Rhododendron, the whole plant isotopic compositions are calculated assuming the roots contribute $25 \%$ to the total mass of the plant

in $\mathrm{Ca}$ as young leaves (Fig. 4; Table 4). The increase in leaf $\mathrm{Ca}$ concentration with age has previously been observed in deciduous trees (Guha and Mitchell 1966) and is due to the lack of retranslocation of $\mathrm{Ca}$, resulting in steady accumulation with time, together with the retranslocation of other nutrients and water loss from older leaves. The observed increase in concentration was most pronounced in Rhododendron leaves and least in Agrostis leaves (Fig. 4). There was an increase in the Ca concentration of Agrostis flowers with age $\left(1.3-2.3 \mathrm{~g} \mathrm{~kg}^{-1}\right)$.

Overall the $\mathrm{Sr} / \mathrm{Ca}$ and the $\mathrm{Ba} / \mathrm{Ca}$ ratios in the leaves (and flowers) increased with age for all species analysed (Fig. 2b). The only exception to this general trend was the $\mathrm{Ba} / \mathrm{Ca}$ ratio of the dead Agrostis leaves which was lower than the 3 month old leaf sample and may have been influenced by leaching and decomposition processes on the ground.

Leaf samples from Rhododendron had a constant $\mathrm{Ca}$ isotopic composition for the first two months $\left(\delta^{44 / 42} \mathrm{Ca}=-0.20 \%\right)$, then became progressively enriched in the heavier isotopes as the leaves aged (Fig. 4; Table 4). In contrast, there was no clear change in the leaf $\mathrm{Ca}$ isotopic compositions of Agrostis and Oxyria as the leaves aged. Both 

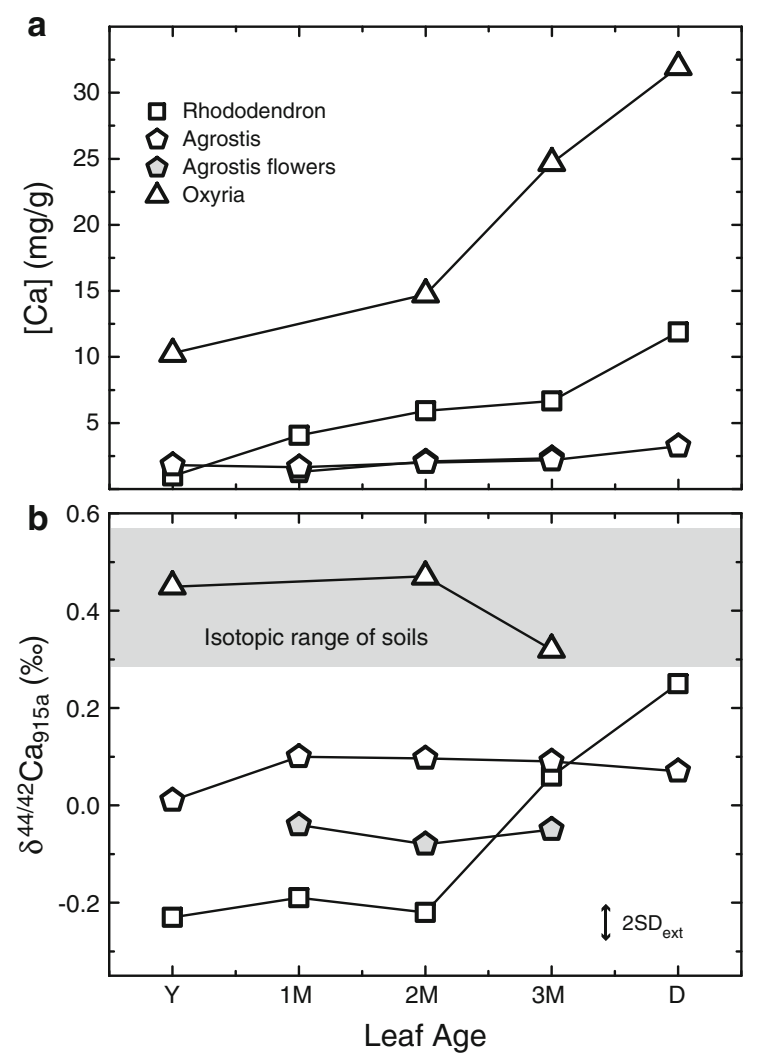

Fig. 4 Variation of calcium concentration (a) and $\delta^{44 / 42} \mathrm{Ca}$ (b) in leaves and flowers (Agrostis only) versus tissue age. The range of $\delta^{44 / 42} \mathrm{Ca}$ values in the soils is indicated by the grey area. For leaf age, $Y$ denotes young leaves sampled in June; $1 M$, $2 M$ and $3 M$ denote leaves sampled 12 and 3 months after young leaves were sampled; and $D$ denotes dead leaves which for Rhododendron were still attached to the plant and for Agrostis were collected as straw

Rhododendron and Agrostis leaves were always isotopically lighter than average soil (0.44 \pm $0.07 \%$ ) whereas Oxyria leaves had an indistinguishable $\mathrm{Ca}$ isotopic composition to soil. No increase in $\mathrm{Ca}$ isotopic composition with age was observed in the flowers of Agrostis and there was a constant $\mathrm{Ca}$ isotopic difference between the leaves and flowers of $\sim 0.15 \%$.

Variation along the chronosequence

Three species were sampled at various points along the chronosequence: L. alpina, Salix $h$. and Salix $r$. (Table 5). Calcium concentrations of L. alpina tended to decrease with soil age, whereas those of the two Salix species tended to increase with soil age (Fig. 5a).
For all species there was no correlation between the $\mathrm{Ca}$ isotopic composition of the above-ground plant parts and soil age (Fig. 5b). The degree of mycorrhizal infection may be expected to influence the $\mathrm{Ca}$ isotopic composition of the plant. There was a general increase of root colonization with soil age across both species (Table 5), but within each species there was a wide range of $\mathrm{Ca}$ isotopic compositions which were not correlated with the percentage of roots infected with mycorrhizal fungi. However, one sample which was not infected had a significantly higher $\delta^{44 / 42} \mathrm{Ca}$ value than all of the infected samples (Fig. 6). Across all species with above-ground biomass data, $\mathrm{Ca}$ concentration was correlated with $\mathrm{Ca}$ isotopic composition $\left(r^{2}=0.52, p<0.01\right.$ across all species, Fig. 7) with a stronger enrichment in light $\mathrm{Ca}$ isotopes relative to soil at lower $\mathrm{Ca}$ concentrations. $\mathrm{Sr} / \mathrm{Ca}$ and $\mathrm{Ba} / \mathrm{Ca}$ ratios were neither correlated with soil age, $\mathrm{Ca}$ isotopic composition nor $\mathrm{Ca}$ concentrations in the aboveground biomass of these plants.

\section{Discussion}

It is clear from the variation in above-ground $\mathrm{Ca}$ isotopic compositions that $\mathrm{Ca}$ isotope fractionation is species dependent and that there is also significant intra-species variability in above-ground $\mathrm{Ca}$ isotopic compositions (Fig. 7). We will first discuss Ca uptake processes and then discuss possible causes of withinplant $\mathrm{Ca}$ isotope fractionation.

\section{Calcium uptake processes}

Significant Ca isotope fractionation occurs between the soil and the roots of Rhododendron (Fig. 3), as was also observed for several tree species (Wiegand et al. 2005; Page et al. 2008; Cenki-Tok et al. 2009; Holmden and Bélanger 2010). Fractionation is either occurring at the soil-plant interface, or the plant accesses a source of isotopically light $\mathrm{Ca}$.

A specific soil pool, for example exchangeable $\mathrm{Ca}$, could be a potential source of light $\mathrm{Ca}$. However, all the root samples were more than $0.24 \%$ lighter in $\delta^{44 / 42} \mathrm{Ca}$ than the lightest $\delta^{44 / 42} \mathrm{Ca}$ value reported from the porewater and soil sequential extraction measurements (Hindshaw et al. 2011) and therefore additional fractionation must occur between these pools and 
Table $4 \mathrm{Ca}$

concentrations, $\delta^{44 / 42} \mathrm{Ca}$ and element ratios for samples collected at various times throughout the season
Table $5 \mathrm{Ca}$

concentrations, $\delta^{44 / 42} \mathrm{Ca}$ and element ratios for plants (above-ground biomass only) along the chronosequence

\begin{tabular}{|c|c|c|c|c|}
\hline Sample & [Ca] $(\mathrm{g} / \mathrm{kg})$ & $\mathrm{Sr} / \mathrm{Ca}(\mathrm{mmol} / \mathrm{mol})$ & $\mathrm{Ba} / \mathrm{Ca}(\mathrm{mmol} / \mathrm{mol})$ & $\begin{array}{l}\delta^{44 / 42} \mathrm{Ca} \\
2 \sigma_{\mathrm{SD}}=0.07 \%\end{array}$ \\
\hline \multicolumn{5}{|c|}{ Rhododendron ferrugineum leaves } \\
\hline Young & 0.99 & 0.48 & 2.47 & -0.23 \\
\hline 1 month & 4.07 & 0.60 & 3.01 & -0.19 \\
\hline 2 months & 5.93 & 0.69 & 3.48 & -0.22 \\
\hline 3 months & 6.67 & 0.63 & 2.96 & 0.06 \\
\hline Dead & 11.9 & 0.83 & 3.51 & 0.25 \\
\hline \multicolumn{5}{|c|}{ Oxyria digyna leaves } \\
\hline Young & 10.2 & 0.96 & 0.58 & 0.45 \\
\hline 2 months & 14.7 & 0.69 & 0.71 & 0.47 \\
\hline 3 months & 24.7 & 1.06 & 1.04 & 0.32 \\
\hline \multicolumn{5}{|c|}{ Agrostis leaves } \\
\hline Young & 1.81 & 1.01 & 1.78 & 0.01 \\
\hline 1 month & 1.65 & 1.15 & 2.67 & 0.10 \\
\hline 2 months & 1.99 & 1.11 & 2.52 & 0.10 \\
\hline 3 months & 2.19 & 1.12 & 2.58 & 0.09 \\
\hline Dead & 3.24 & 1.30 & 1.71 & 0.07 \\
\hline \multicolumn{5}{|c|}{ Agrostis flowers } \\
\hline 1 month & 1.30 & 0.90 & 2.29 & -0.04 \\
\hline 2 months & 2.09 & 1.25 & 2.85 & -0.08 \\
\hline 3 months & 2.32 & 1.16 & 3.03 & -0.05 \\
\hline
\end{tabular}

\begin{tabular}{|c|c|c|c|c|c|c|}
\hline Sample & $\begin{array}{l}\text { Soil } \\
\text { age } \\
\text { (years) }\end{array}$ & $\begin{array}{l}{[\mathrm{Ca}]} \\
(\mathrm{g} / \mathrm{kg})\end{array}$ & $\begin{array}{l}\mathrm{Sr} / \mathrm{Ca} \\
(\mathrm{mmol} / \\
\mathrm{mol})\end{array}$ & $\begin{array}{l}\mathrm{Ba} / \mathrm{Ca} \\
(\mathrm{mmol} / \\
\mathrm{mol})\end{array}$ & $\begin{array}{l}\delta^{44 / 42} \mathrm{Ca} \\
2 \sigma_{\mathrm{SD}}=0.07 \%\end{array}$ & $\begin{array}{l}\% \text { of } \\
\text { mycorrhizal } \\
\text { root colonization }\end{array}$ \\
\hline \multirow[t]{8}{*}{ L. alpina } & 7 & 11.8 & 1.42 & 1.27 & 0.34 & 0 \\
\hline & 8 & 12.1 & 1.80 & 1.18 & 0.19 & 34 \\
\hline & 14 & 9.82 & 1.45 & 0.97 & 0.21 & 38 \\
\hline & 59 & 7.58 & 2.45 & 3.03 & 0.13 & 55 \\
\hline & 65 & 7.44 & 2.63 & 4.16 & 0.24 & 66 \\
\hline & 68 & 6.46 & 1.57 & 1.58 & 0.23 & 47 \\
\hline & 73 & 8.32 & 1.65 & 2.46 & 0.15 & 72 \\
\hline & 76 & 6.77 & 1.55 & 2.25 & 0.16 & 30 \\
\hline \multirow[t]{5}{*}{ Salix $h}$. & 7 & 2.89 & 0.99 & 0.42 & 0.11 & 28 \\
\hline & 67 & 5.29 & 2.08 & 4.12 & 0.05 & 22 \\
\hline & 73 & 7.31 & 1.72 & 1.38 & 0.14 & 47 \\
\hline & 78 & 3.52 & 1.69 & 3.13 & 0.06 & 23 \\
\hline & 79 & 4.87 & 1.94 & 1.73 & -0.02 & 35 \\
\hline \multirow[t]{2}{*}{ Salix $r$} & 59 & 1.43 & 3.19 & 6.28 & -0.04 & 39 \\
\hline & 129 & 4.91 & 1.71 & 0.34 & 0.10 & 70 \\
\hline \multicolumn{7}{|c|}{ Ectomycorrhizal sporocaps } \\
\hline $\begin{array}{l}\text { Laccaria } \\
\text { montana }\end{array}$ & & 0.61 & 2.59 & 7.95 & 0.21 & \\
\hline $\begin{array}{l}\text { Russula } \\
\text { exalbicans }\end{array}$ & & 0.32 & 3.44 & 9.07 & 0.23 & \\
\hline
\end{tabular}



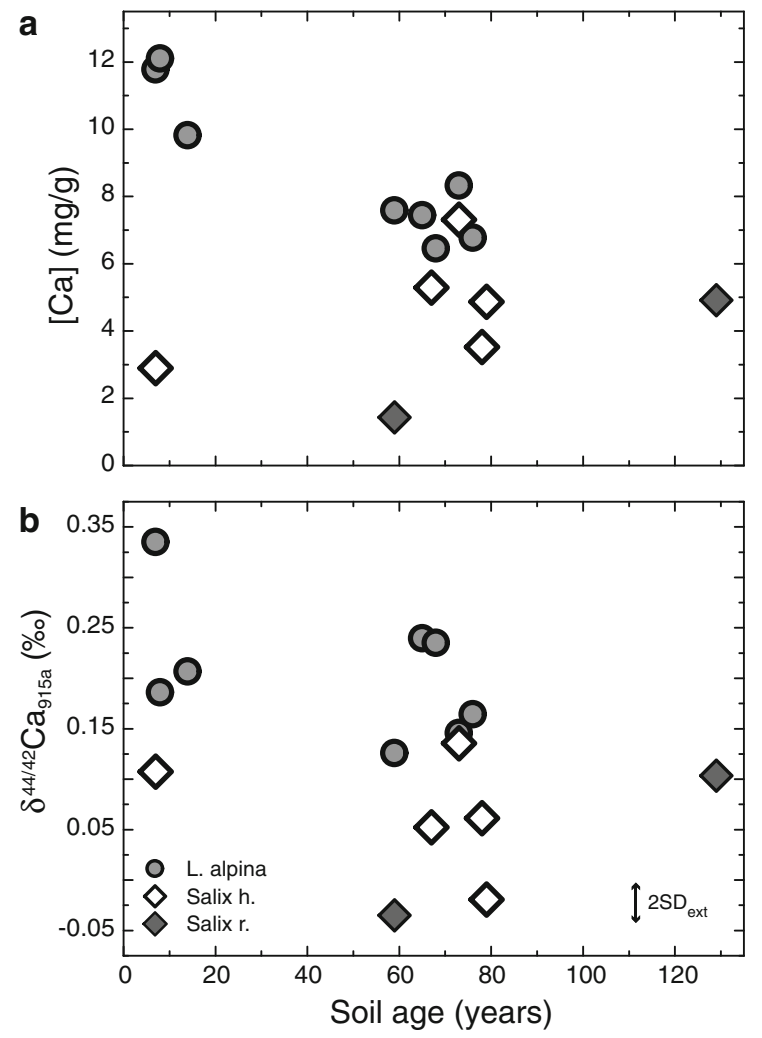

Fig. 5 Ca concentration (a) and Ca isotopic composition (b) of the above-ground biomass of three plant species versus soil age. Across all three species soil age had no effect on the $\mathrm{Ca}$ concentration or the $\mathrm{Ca}$ isotopic composition of the plant

plant roots. Mycorrhiza act as an additional interface between the soil and the plant, thus the extent of $\mathrm{Ca}$ fractionation in a plant might be expected to depend on the percentage of root area infected with mycorrhiza. However, no clear relationship between the extent of root infection and above-ground $\mathrm{Ca}$ isotopic composition was found (Fig. 6), suggesting that mycorrhiza are not the main control of plant $\mathrm{Ca}$ isotopic compositions.

We consider it likely that the isotopic difference between plant roots and soil arises due to a fractionation process occurring during the uptake of $\mathrm{Ca}$ into plant roots. Ca uptake is by mass flow, i.e. passive uptake driven by transpiration (Marschner 1995) and this process is not expected to cause $\mathrm{Ca}$ isotope fractionation. Within the root, Ca transport is predominantly apoplastic (between cells, Fig. 1b), partly due to the toxicity of high levels of cytoplasmic Ca (e.g. McLaughlin and Wimmer 1999). The presence of the endodermis, a hydrophobic layer of cells in fully

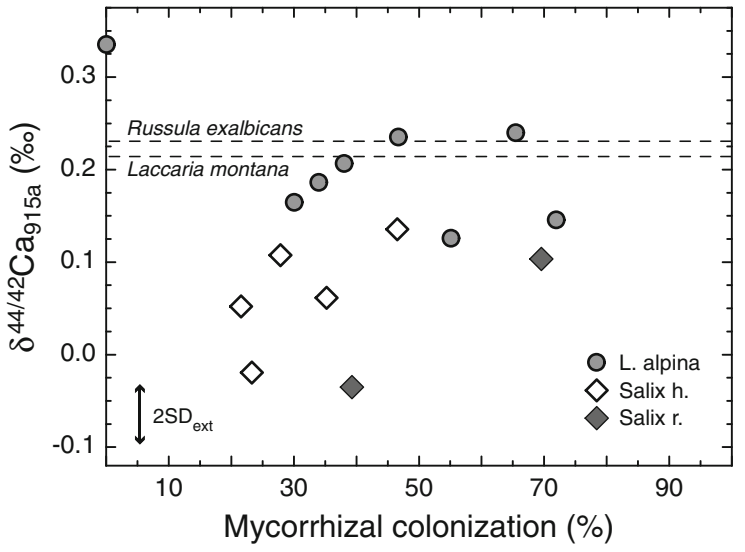

Fig. $6 \delta^{44 / 42} \mathrm{Ca}$ in above-ground biomass plotted against the percentage of roots infected with mycorrhizal fungi for three different plant species. The measured $\mathrm{Ca}$ isotopic composition for the sporocaps of two species of ectomycorrhizal fungi collected from the forefield are indicated by the dotted lines. There is no clear relationship between the percentage of roots infected and above-ground $\delta^{44 / 42} \mathrm{Ca}$ values, but a single specimen of L. alpina which has no mycorrhiza is notably heavier than the rest of the specimens

developed root cells, prevents apoplastic Ca transport from the cortex (outer root) to the stele (inner root) (Fig. 1a). Transport across the endodermis is symplastic (within cell) requiring transport proteins (White and Broadley 2003). This would be expected to induce measurable isotope fractionation between the cortex and the stele as was recently observed for iron (Kiczka et al. 2010). The fact that the cortex and the stele of Rhododendron had the same isotopic composition strongly supports the view that Ca uptake is primarily apoplastic (between cells) and the majority of uptake must therefore occur at the root apices where the endodermis has not yet developed (e.g. Karley and White 2009). Calcium isotope fractionation must therefore occur in the cortex. Studies utilising isotopically labelled solutions have shown biphasic uptake behaviour for divalent cations (Epstein and Leggett 1954; Drew and Biddulph 1971) with an adsorbed and an absorbed component. As defined by Epstein and Leggett (1954), adsorption is a passive process which results in a readily exchangeable component and absorption is an active process resulting in an essentially non-exchangeable component. Both adsorption and absorption processes could fractionation $\mathrm{Ca}$ isotopes, resulting in the difference in isotopic composition observed between roots and soil. 

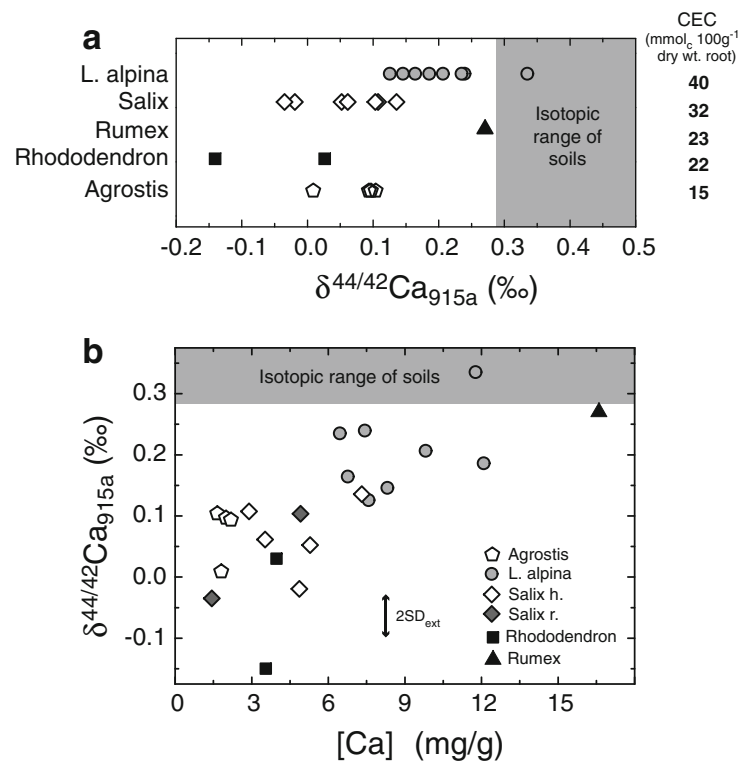

Fig. 7 a Summary of above-ground Ca isotopic compositions of species analysed. The root CEC for the different plant species at the order level (White and Broadley 2003) is shown for comparison. Within the dicotyledonous species (all except Agrostis) the whole plant $\mathrm{Ca}$ isotopic composition appears to increase with increasing root CEC. Rumex does not follow the trend of increasing $\delta^{44 / 42} \mathrm{Ca}$ values with increasing root CEC observed in the other dicotyledonous species. This may be due to the precipitation of $\mathrm{Ca}$ oxalate in the root cortex. $\mathbf{b}$ Across all species, there is a correlation $\left(r^{2}=0.52, p<0.01\right)$ between the concentration of $\mathrm{Ca}$ (dry weight) and the above-ground $\mathrm{Ca}$ isotopic composition. This suggests that root level Ca uptake processes, i.e. the amount of $\mathrm{Ca}$ adsorption, determined by root $\mathrm{CEC}$, could control the overall plant $\mathrm{Ca}$ isotopic composition

The absorbed phase is essentially irreversibly bound $\mathrm{Ca}$ which has undergone active transport into cells. Due to low cytoplasmic Ca concentrations, an electrochemical gradient exists from the apoplasm (mmol L ${ }^{-1} \mathrm{Ca}$ ) into the cell $\left(\mathrm{nmol} \mathrm{L}{ }^{-1} \mathrm{Ca}\right)$. Calcium in the cytoplasm is actively removed by pumping it into the vacuole or back out of the cell across the cell membrane. This is achieved by calcium ATPase and $\mathrm{Ca}^{2+} / \mathrm{H}^{+}$antiporters (Evans et al. 1991; Fig. 1c). We hypothesise that these active processes will favour the transport of light $\mathrm{Ca}$ as a result of incomplete kinetic reactions, resulting in an accumulation of light $\mathrm{Ca}$ inside the cell vacuole.

The adsorbed phase is readily exchangeable with the soil solution and it has been shown that the adsorption of magnesium by root cells induces isotope fractionation with the adsorbed phase enriched in heavy Mg isotopes (Bolou-Bi et al. 2010). Therefore, it is reasonable to assume that $\mathrm{Ca}$ isotopes will also fractionate during adsorption. Adsorption is likely to be an equilibrium fractionation process whereby the stronger bonding environment is enriched in the heavier isotopes. The most common adsorption sites for $\mathrm{Ca}$, and other metals, in the apoplasm are carboxyl groups located in the cell walls (Marschner 1995). Recent root desorption experiments indicate that the adsorbed phase is enriched in light $\mathrm{Ca}$ isotopes (Cobert et al. 2011) and this is supported by estimates of bond lengths, which are a proxy for the strength of the bond. During equilibrium fractionation, the heavy isotopes are enriched in the stiffer (shorter) bonds (Bigeleisen 1965). Spectroscopic methods and density functional theory calculations indicate that the $\mathrm{Ca}-\mathrm{O}$ bond length of hydrated Ca (2.4 ̊) (Carugo et al. 1993; Kaufman Katz et al. 1996; Pavlov et al. 1998; Jalilehvand et al. 2001) is shorter than that of the $\mathrm{Ca}-\mathrm{O}$ bond in a bidentate $\mathrm{Ca}$ carboxylate crystal structure $(2.5 \AA)$ (Einspahr and Bugg 1981; Carugo et al. 1993; Wong et al. 2006). Based on these results, the adsorbed phase with the weaker, longer bond should be enriched in light $\mathrm{Ca}$. The extent of this fractionation would be dependent on the number of available exchange sites, the functional groups present and the extent of equilibration with the soil solution. Thus, both adsorption and absorption are capable of causing isotope fractionation in the same direction and could be responsible for the light $\mathrm{Ca}$ isotopic composition of root tissue compared to soil.

Within-plant fractionation processes

The processes involved in fractionating $\mathrm{Ca}$ isotopes once $\mathrm{Ca}$ is within the plant are not well understood and we have no definitive explanations for the fractionation patterns detected. In the interest of guiding future research, we propose some potential processes in the next section which could be responsible for the withinplant fractionation patterns we observed.

\section{Root to leaf and reproductive organs}

In the two Rhododendron specimens analysed, excluding the flowers, negligible within-plant $\mathrm{Ca}$ isotope fractionation along the transpiration stream was observed (Table 3), whereas internal fractionation was observed in Rumex. 
Rumex and Oxyria are closely related species and both had heavier $\mathrm{Ca}$ isotopic compositions $\left(\delta^{44 / 42} \mathrm{Ca}=\sim 0.40 \%\right)$ in their leaves and flowers compared to root tissue. With respect to the whole plant $\mathrm{Ca}$ isotopic composition, the roots were $0.28 \%$ lighter and the leaves $0.24 \%$ heavier. These two plants are known to contain high levels of oxalate in order to deter grazers (Landolt and Urbanska 2003) and $\mathrm{Ca}$ oxalate crystals can occur in all parts of the plant (Doaigey 1991). Calcium oxalate crystals were observed under a microscope in root samples from Rumex. Ca oxalate contains a $\mathrm{Ca}-$ carboxylate bond and is predicted to be enriched in light $\mathrm{Ca}$ isotopes, based on bond-length arguments outlined above (see "Calcium uptake processes" section). The concentration of $\mathrm{Ca}$ in the cortex was extremely high $(22 \mathrm{~g} / \mathrm{kg}$, cf. $1 \mathrm{~g} / \mathrm{kg}$ for Rhododendron) and this, together with the $0.25 \%$ increase in $\delta^{44 / 42} \mathrm{Ca}$ between the cortex and the stele, strongly suggests that calcium oxalate is precipitating within the cortex. We suggest that the $\delta^{44 / 42} \mathrm{Ca}$ of xylem fluid is further increased during passage through the stem due to further oxalate precipitation, resulting in the observed heavy isotopic composition of the leaves and flowers.

Previous studies (Wiegand et al. 2005; Page et al. 2008; Holmden and Bélanger 2010), observed an increase in $\delta^{44 / 42} \mathrm{Ca}$ from root to leaf, consistent with laboratory ion exchange experiments by Russell and Papanastassiou (1978) which showed that light Ca isotopes were preferentially retained. The decrease of $\mathrm{Ba} / \mathrm{Ca}$ and $\mathrm{Sr} / \mathrm{Ca}$ ratios from stele to stem to leaf in Rhododendron (Fig. 2a) is consistent with the occurrence of ion exchange during transport through the xylem (Ferguson and Bollard 1976; Van de Geijn and Petit 1979) and has been observed in plants from a wide range of ecosystems (Bailey et al. 1996; Poszwa et al. 2000; Drouet and Herbauts 2008; Pett-Ridge et al. 2009). However, we observed no clear increase in $\delta^{44 / 42} \mathrm{Ca}$ values from root to leaf in Rhododendron. Russell and Papanastassiou (1978) predicted that longer ion exchange columns would induce more $\mathrm{Ca}$ isotope fractionation than shorter columns, as this amplifies the difference in transit time between light and heavy isotopes. By analogy, since the stem of Rhododendron is much shorter than in trees, we suggest that the length of the xylem 'ion-exchange column' was not long enough to produce significant $\mathrm{Ca}$ isotope fractionation. This is analogous to the explanation proposed by Viers et al. (2007) for the different $\mathrm{Zn}$ isotopic compositions of herbs and trees.

The flowers of Rhododendron were $0.20 \%$ lighter in $\delta^{44 / 42} \mathrm{Ca}$ in both specimens analysed compared to the bulk plant isotopic composition. The flowers of Agrostis were also lighter by $0.15 \%$ than the leaf+stem $\delta^{44 / 42} \mathrm{Ca}$ value. The flowers contain the reproductive organs of the plant and these tissues acquire $\mathrm{Ca}$ from the phloem (Marschner 1995). Ca reaches the phloem by symplastic transport (Marschner 1995; Fig. 1a) and is thus expected to be isotopically light due to kinetically controlled isotope fractionation during transport of $\mathrm{Ca}$ across cell membranes.

\section{Seasonal variation in leaf Ca isotopic composition}

Significant increases over the growing season were observed in the $\mathrm{Ca}$ isotopic compositions and $\mathrm{Ca}$ concentrations of Rhododendron leaves, but no increase in $\delta^{44 / 42} \mathrm{Ca}$ was observed in Oxyria or Agrostis leaves.

Unlike most other plant nutrients, the retranslocation of Ca from leaves is negligible (Marschner 1995), thus changes in leaf $\delta^{44 / 42} \mathrm{Ca}$ with age must either arise from a change in the $\mathrm{Ca}$ isotopic composition of the xylem fluid, which is the source of $\mathrm{Ca}$ to the leaf, or as a result of a change in whole leaf $\mathrm{Ca}$ isotopic composition during the loss of $\mathrm{Ca}$ through leaching by rainwater.

As leaves age, they take up less $\mathrm{Ca}$ from the xylem (Clarkson 1984) and the leaching rate increases due to an increase in the permeability of cell membranes (Marschner 1995). A reduction in the uptake of $\mathrm{Ca}$ could explain the increase in $\mathrm{Ba} / \mathrm{Ca}$ and $\mathrm{Sr} / \mathrm{Ca}$ ratios observed in all three species (Fig. 2b). The Ca inside cells is expected to be isotopically light due to absorption. If this isotopically light $\mathrm{Ca}$ was leached it could explain the increase in the $\mathrm{Ca}$ isotopic composition of Rhododendron leaves. The lack of change in leaf $\delta^{44 / 42} \mathrm{Ca}$ of Oxyria and Agrostis could be due to differences in leaf morphology and physiology.

Alternatively, a change in the $\mathrm{Ca}$ isotopic composition of the xylem fluid could change Rhododendron leaf $\delta^{44 / 42} \mathrm{Ca}$ over the season. Ferguson and Bollard (1976) demonstrated for trees, using a ${ }^{45} \mathrm{Ca}$ tracer, that 
in autumn, compared to spring, xylem fluid transport was retarded and that this was due to lignin deposition increasing the CEC of the xylem. An increased CEC of the stem would be expected to result in decreasing $\mathrm{Ba} /$ $\mathrm{Ca}$ and $\mathrm{Sr} / \mathrm{Ca}$ ratios with leaf age, as the heavier cations are more strongly retained on the exchange sites. Such a seasonal decrease was observed by Guha and Mitchell (1966) in sycamore leaves (Acer pseudoplatanus). In autumn, secondary xylem growth results in smaller cells compared to growth in spring with a corresponding increase in cell wall growth, for which $\mathrm{Ca}$ is a major component (McLaughlin and Wimmer 1999). The relative increased demand for $\mathrm{Ca}$ from the stem tissue in autumn (involving active uptake) could lead to an increased $\delta^{44 / 42} \mathrm{Ca}$ value of the xylem fluid and the increase in leaf $\mathrm{Ba} / \mathrm{Ca}$ and $\mathrm{Sr} / \mathrm{Ca}$ ratios observed (Fig. 2b). If correct, this seasonal change in leaf $\delta^{44 / 42} \mathrm{Ca}$ values would only be observed in plants with woody stems.

\section{Intercomparison of alpine plant species}

Root CEC is thought to be important in controlling Ca uptake (Haynes 1980) and because above-ground $\delta^{44 / 42} \mathrm{Ca}$ values and Ca concentrations were correlated (Fig. 7b), root CEC may also control above-ground $\mathrm{Ca}$ isotopic compositions. Within the dicotyledonous species there is a trend of increasing above-ground $\mathrm{Ca}$ isotopic composition and $\mathrm{Ca}$ concentration with increased root CEC (Fig. 7). The greater the number of adsorption sites (higher CEC) the closer the $\mathrm{Ca}$ isotopic composition of the plant is to soil (source $\mathrm{Ca}$ ). Rumex does not lie on this trend, which may be due to the additional effect of oxalate precipitation. The heterogeneity in soil $\delta^{44 / 42} \mathrm{Ca}$ values and variations in hydrology could contribute to the observed variability in above-ground $\mathrm{Ca}$ isotopic compositions within a single species. Agrostis was the only monocotyledonous species analysed and its relatively high aboveground $\mathrm{Ca}$ isotope ratio could be due to differences in both the composition of the root cell walls (Hose et al. 2001) and demand for Ca between monocotyledonous and dicotyledonous species. Thus, whole plant $\delta^{44 / 42} \mathrm{Ca}$ values could be largely determined by the root CEC which is species specific, but this hypothesis requires further experimental verification.
Comparison with $\mathrm{Sr}$

Strontium and calcium are expected to behave similarly during plant uptake and translocation, due to their similar chemical properties. It is also expected that the stable isotopes of these two elements should have similar within-plant fractionation patterns. However, a previous study of stable Sr isotope fractionation within Rhododendron plants at the Damma glacier fieldsite (de Souza et al. 2010) concluded that Sr fractionated in the opposite sense to $\mathrm{Ca}$ during within-plant fractionation based on a comparison with previously published $\mathrm{Ca}$ isotope data on trees (Wiegand et al. 2005; Page et al. 2008). This study measured Rhododendron from the same fieldsite (different specimens) allowing the stable isotope fractionation of $\mathrm{Sr}$ and $\mathrm{Ca}$ to be directly compared in the same species. Our results indicate that the discrepancy is probably due to comparison between different species, and directly comparing stable $\mathrm{Ca}$ and $\mathrm{Sr}$ isotope ratios relative to soil from the same species (Rhododendron) shows that the direction of stable isotope fractionation between soil and different tissues is the same (Table 6). In Rhododendron, both within leaves of different age and between different tissues, there is a strong correlation of $\mathrm{Ca}$ and $\mathrm{Sr}$ concentrations $\left(r^{2}=0.97\right.$ and 0.80 respectively), suggesting that these two elements are behaving similarly within the plant. The similarity between $\mathrm{Sr}$ and $\mathrm{Ca}$ stable isotope fractionation in plants indicates that either the active transport mechanisms cannot distinguish between $\mathrm{Ca}$ and $\mathrm{Sr}$

Table 6 Comparison of stable $\mathrm{Ca}$ and $\mathrm{Sr}$ isotope ratios relative to soil in Rhododendron (different specimens)

\begin{tabular}{|c|c|c|c|c|}
\hline \multirow[t]{2}{*}{ ‘ } & \multicolumn{2}{|l|}{$\mathrm{Sr}(\%)$} & \multicolumn{2}{|l|}{$\mathrm{Ca}(\%)$} \\
\hline & $\Delta^{88 / 86} \mathrm{Sr}^{\mathrm{a}}$ & $95 \% \mathrm{CL}^{\mathrm{b}}$ & $\Delta^{44 / 42} \mathrm{Ca}$ & $2 \sigma_{\mathrm{SD}}$ \\
\hline \multirow[t]{3}{*}{ Root-soil } & -0.29 & 0.14 & -0.34 & 0.10 \\
\hline & -0.18 & 0.10 & -0.47 & 0.10 \\
\hline & & & -0.37 & 0.10 \\
\hline \multirow[t]{2}{*}{ Flower-soil } & -0.54 & 0.14 & -0.58 & 0.10 \\
\hline & & & -0.69 & 0.10 \\
\hline \multirow[t]{2}{*}{ Stem-soil } & -0.24 & 0.14 & -0.29 & 0.10 \\
\hline & & & -0.54 & 0.10 \\
\hline
\end{tabular}

a All Sr data from de Souza et al. (2010)

b CL stands for confidence limit 
and/or that adsorption fractionates both cations similarly as a result of both cations competing for identical adsorption sites (Epstein and Leggett 1954).

Effect of plants in the biogeochemical Ca cycle

Plants strongly fractionate $\mathrm{Ca}$ isotopes compared to soil pools, and would thus be expected to impact soil pool Ca isotope values. No influence of plants on soil, water or porewater $\delta^{44 / 42} \mathrm{Ca}$ was detected in this catchment, due to the very low vegetation density (Hindshaw et al. 2011). However, the effect of plants on $\mathrm{Ca}$ cycling is likely to change as vegetation succession proceeds. Calcium from litterfall can be mobilised and re-used by plants, but its composition is species dependent: old Rhododendron leaves had a Ca isotopic composition identical to soil whereas those of Agrostis had a lighter isotopic composition. In addition, as vegetation succession proceeds an increasing proportion of $\mathrm{Ca}$ is incorporated into biomass, especially into woody tissues. In the late stages of vegetation succession the size of the $\mathrm{Ca}$ pool in plants can exceed that of the exchangeable pool (Johnson 1992). Thus, it is conceivable that during succession, the $\mathrm{Ca}$ isotopic composition of plant-available soil pools will change as a result of vegetation development and this could potentially affect porewater and thus stream water isotopic compositions. However, it is unclear how important vegetation succession versus mineral weathering is in controlling the dissolved fluxes of streams (Gorham et al. 1979; Taylor and Velbel 1991). Ultimately the Ca isotopic composition of stream water will depend on the relative size of the respective fluxes. For example, Holmden and Bélanger (2010) found that $80 \%$ of the Ca in stream water in a forested watershed in Saskatchewan was biologically derived despite $90 \%$ of $\mathrm{Ca}$ being internally recycled. Calcium isotope variability in the Strengbach catchment (France) has been attributed to seasonal vegetation control (Schmitt et al. 2003; Cenki-Tok et al. 2009). On the other hand, Tipper et al. (2006, 2008) concluded that vegetation did not affect the $\mathrm{Ca}$ isotopic compositions of Himalayan rivers. These results are not contradictory, Saskatchewan is located on the Precambrian Shield and the mineral weathering rates of shield terrains are generally low. The Himalaya however, are typified by high chemical (and physical) weathering rates. Thus, where mineral weathering rates are low, fractionated reservoirs of Ca due to biological activity may be observed. In such locations, large-scale ecosystem disturbances such as forest fires or clear cutting, which are known to cause high transient $\mathrm{Ca}$ fluxes as $\mathrm{Ca}$ is released from decaying humic matter (Likens et al. 1970; BaloghBrunstad et al. 2008), could cause significant changes in soil pool and runoff $\delta^{44 / 42} \mathrm{Ca}$ values.

\section{Conclusions}

Several species of plants collected from a recently glaciated, granitic catchment were shown to have a bulk $\mathrm{Ca}$ isotopic composition which was isotopically lighter than soil, but the magnitude of $\Delta^{44 / 42} \mathrm{Ca}_{\text {plant-soil }}$ was strongly species dependent and was not dependent on soil age. The $\mathrm{Ca}$ isotope fractionation patterns observed in Rhododendron can be explained by two processes: equilibrium fractionation during adsorption of Ca onto carboxyl groups located on cell walls, resulting in an isotopically light adsorbed phase and kinetic fractionation during active uptake by cells resulting in the accumulation of light $\mathrm{Ca}$ inside cells. Comparing all species, the higher the $\mathrm{Ca}$ concentration of the plant, the smaller the $\mathrm{Ca}$ isotope fractionation relative to soil, with high $\mathrm{Ca}$ concentrations linked to high root CEC. This observation suggests that the amount of adsorption of $\mathrm{Ca}$ by roots may be an important factor in determining the $\mathrm{Ca}$ isotopic composition of the plant.

Calcium is an essential plant nutrient and stable $\mathrm{Ca}$ isotopes have the potential to refine our understanding of plant uptake and utilisation processes. This study only analysed bulk plant tissues. The next step would be to analyse plant tissues in finer detail e.g. tree rings and xylem fluid and exploit the combination of stable isotopes and radioactive tracers. In addition, $\mathrm{Ca}$ isotope fractionation during adsorption remains to be experimentally verified and the form of binding during adsorption investigated. The results from this study indicate that stable $\mathrm{Ca}$ isotopes are a promising tool for understanding the biogeochemical Ca cycle in terrestrial environments and elucidating species differences in $\mathrm{Ca}$ utilisation by plants.

Acknowledgments The authors would like to thank Gregory de Souza for insightful discussions regarding the stable isotope fractionation of $\mathrm{Sr}$ and $\mathrm{Ca}$ by plants, Monika Welc for 
measuring the mycorrhizal infection of root samples and providing the 'chronosequence' and mycorrhizal sporocap samples and Hans Göransson for his help in understanding plant biology and in choosing suitable plant species to study. We thank associate editor Steven Perakis and two reviewers for their constructive reviews of this manuscript. In particular we are indebted to Thomas Bullen for his very detailed and thoughtprovoking reviews which considerably improved this manuscript. This work was associated with the BigLink project of the Competence Center Environment and Sustainability of the ETH Domain (CCES) and was funded by ETH Research Grant No. 04/06-3.

\section{References}

Bailey SW, Hornbeck JW, Driscoll CT, Gaudette HE (1996) Calcium inputs and transport in a base-poor forest ecosystem as interpreted by $\mathrm{Sr}$ isotopes. Water Resour Res 32:707-719

Balogh-Brunstad Z, Keller CK, Bormann BT, O'Brien R, Wang D, Hawley G (2008) Chemical weathering and chemical denudation dynamics through ecosystem development and disturbance. Glob Biogeochem Cycles 22:GB1007

Bernasconi SM, Bauder A, Bourdon B, Brunner I, Bünemann E, Christl I, Derungs N, Edwards P, Farinotti D, Frey B, Frossard E, Furrer G, Gierga M, Göransson H, Gülland K, Hagedorn F, Hajdas I, Hindshaw R, Ivy-Ochs S, Jansa J, Jonas T, Kiczka M, Kretzschmar R, Lemarchand E, Luster J, Magnusson J, Mitchell E, Olde Venterink H, Plötze M, Reynolds B, Smittenberg RH, Stähli M, Tamburini F, Tipper E, Wacker L, Welc M, Wiederhold JG, Zeyer J, Zimmermann S, Zumsteg A (2011) Chemical and biological gradients along the Damma Glacier soil chronosequence, Switzerland. Vadose Zone J 10:867-883

Bigeleisen J (1965) Chemistry of isotopes. Science 147:463-471

Blum JD, Dasch AA, Hamburg SP, Yanai RD, Arthur MA (2008) Use of foliar $\mathrm{Ca} / \mathrm{Sr}$ discrimination and ${ }^{87} \mathrm{Sr} /{ }^{86} \mathrm{Sr}$ ratios to determine soil $\mathrm{Ca}$ sources to sugar maple foliage in a northern hardwood forest. Biogeochemistry 87:287-296

Bolou-Bi EB, Poszwa A, Leyval C, Vigier N (2010) Experimental determination of magnesium isotope fractionation during higher plant growth. Geochim Cosmochim Acta 74:2523-2537

Bormann BT, Wang D, Bormann FH, Benoit G, April R, Snyder MC (1998) Rapid, plant-induced weathering in an aggrading experimental ecosystem. Biogeochemistry 43:129-155

Bullen TD, Bailey SW (2005) Identifying calcium sources at an acid deposition-impacted spruce forest: a strontium isotope, alkaline earth element multi-tracer approach. Biogeochemistry 74:63-99

Capo RC, Stewart BW, Chadwick OA (1998) Strontium isotopes as tracers of ecosystem processes: theory and methods. Geoderma 82:197-225

Carugo O, Djinović K, Rizzi M (1993) Comparison of the coordinative behaviour of calcium(II) and magnesium(II) from crystallographic data. J Chem Soc Dalton Trans $14: 2127-2135$
Cenki-Tok B, Chabaux F, Lemarchand D, Schmitt AD, Pierret MC, Viville D, Stille P (2009) The impact of water-rock interaction and vegetation on calcium isotope fractionation in soil- and stream waters of a small, forested catchment (the Strengbach case). Geochim Cosmochim Acta 73:2215-2228

Clarkson DT (1984) Calcium transport between tissues and its distribution in the plant. Plant Cell Environ 7:449-456

Cobert F, Schmitt AD, Bourgeade P, Labolle F, Badot PM, Chabaux F, Stille P (2011) Experimental identification of $\mathrm{Ca}$ isotopic fractionations in higher plants. Geochim Cosmochim Acta 75:5467-5482

Dasch AA, Blum JD, Eagar C, Fahey TJ, Driscoll CT, Siccama TG (2006) The relative uptake of $\mathrm{Ca}$ and $\mathrm{Sr}$ into tree foliage using a whole-watershed calcium addition. Biogeochemistry $80: 21-41$

de Souza GF, Reynolds BC, Kiczka M, Bourdon B (2010) Evidence for mass-dependent isotopic fractionation of strontium in a glaciated granitic watershed. Geochim Cosmochim Acta 74:2596-2614

Doaigey AR (1991) Occurence, type, and location of calcium oxalate crystals in leaves and stems of 16 species of poisonous plants. Am J Bot 78:1608-1616

Drever JI (1994) The effect of land plants on weathering rates of silicate minerals. Geochim Cosmochim Acta 58:23252332

Drew MC, Biddulph O (1971) Effect of metabolic inhibitors and temperature on uptake and translocation of ${ }^{45} \mathrm{Ca}$ and ${ }^{42} \mathrm{~K}$ by intact bean plants. Plant Physiol 48:426-432

Drouet T, Herbauts J (2008) Evaluation of the mobility and discrimination of $\mathrm{Ca}, \mathrm{Sr}$ and $\mathrm{Ba}$ in forest ecosystems: consequence on the use of alkaline-earth element ratios as tracers of Ca. Plant Soil 302:105-124

Einspahr H, Bugg CE (1981) The geometry of calcium-carboxylate interactions in crystalline complexes. Acta Crystallogr B 37:1044-1052

Epstein E, Leggett JE (1954) The absorption of alkaline earth cations by barley roots: kinetics and mechanism. Am J Bot 41:785-791

Evans DE, Briars SA, Williams LE (1991) Active calcium transport by plant cell membranes. J Exp Bot 42:285-303

Ferguson IB, Bollard EG (1976) The movement of calcium in woody stems. Ann Bot 40:1057-1065

Giovannetti M, Mosse B (1980) An evaluation of techniques for measuring vesicular arbuscular mycorrhizal infection in roots. New Phytol 84:489-500

Gorham E, Vitousek PM, Reiners WA (1979) The regulation of chemical budgets over the course of terrestrial ecosystem succession. Annu Rev Ecol Syst 10:53-84

Guha MM, Mitchell RL (1966) The trace and major element composition of the leaves of some deciduous trees II. Seasonal changes. Plant Soil 24:90-112

Haynes RJ (1980) Ion exchange properties of roots and ionic interactions within the root apoplasm: their role in ion accumulation by plants. Bot Rev 46:75-99

Hindshaw RS, Reynolds BC, Wiederhold JG, Kretzschmar R, Bourdon B (2011) Calcium isotopes in a proglacial weathering environment: Damma glacier, Switzerland. Geochim Cosmochim Acta 75:106-118

Holmden C, Bélanger N (2010) Ca isotope cycling in a forested ecosystem. Geochim Cosmochim Acta 74:995-1015 
Hose E, Clarkson DT, Steudle E, Schreiber L, Hartung W (2001) The exodermis: a variable apoplastic barrier. J Exp Bot 52:2245-2264

Jalilehvand F, Spångberg D, Lindqvist-Reis P, Hermansson K, Persson I, Sandström M (2001) Hydration of the calcium ion. An EXAFS, large-angle X-ray scattering, and molecular dynamics simulation study. J Am Chem Soc 123:431-441

Johnson DW (1992) Base cation distribution and cycling. In: Johnson DW, Lindberg SE (eds) Atmospheric deposition and forest nutrient cycling, Springer, New York, pp 275-332

Karley AJ, White PJ (2009) Moving cationic minerals to edible tissues: potassium, magnesium, calcium. Curr Opin Plant Biol 12:291-298

Kaufman Katz A, Glusker JP, Beebe SA, Bock CW (1996) Calcium ion coordination: a comparison with that of beryllium, magnesium, and zinc. J Am Chem Soc 118:5752-5763

Kiczka M, Wiederhold JG, Kraemer SM, Bourdon B, Kretzschmar R (2010) Iron isotope fractionation during Fe uptake and translocation in alpine plants. Environ Sci Technol 44:6144-6150

Landolt E, Urbanska KM (2003) Our alpine flora. SAC Verlag, Chur

Likens GE, Bormann FH, Johnson NM, Fisher DW, Pierce RS (1970) Effects of forest cutting and herbicide treatment on nutrient budgets in the Hubbard Brook watershed-ecosystem. Ecol Monogr 40:23-47

Likens GE, Driscoll CT, Buso DC, Siccama TG, Johnson CE, Lovett GM, Fahey TJ, Reiners WA, Ryan DF, Martin CW, Bailey SW (1998) The biogeochemistry of calcium at Hubbard Brook. Biogeochemistry 41:89-173

Marschner H (1995) Mineral nutrition of higher plants. Academic Press, London

McLaughlin SB, Wimmer R (1999) Calcium physiology and terrestrial ecosystem processes. New Phytol 142:373417

Page BD, Bullen TD, Mitchell MJ (2008) Influences of calcium availability and tree species on $\mathrm{Ca}$ isotope fractionation in soil and vegetation. Biogeochemistry 88:1-13

Pavlov M, Siegbahn PEM, Sandström M (1998) Hydration of beryllium, magnesium, calcium, and zinc ions using density functional theory. J Phys Chem A 102:219-228

Pett-Ridge JC, Derry LA, Barrows JK (2009) $\mathrm{Ca} / \mathrm{Sr}$ and ${ }^{87} \mathrm{Sr} /{ }^{86} \mathrm{Sr}$ ratios as tracers of $\mathrm{Ca}$ and $\mathrm{Sr}$ cycling in the Rio
Icacos watershed, Luquillo Mountains, Puerto Rico. Chem Geol 267:32-45

Poszwa A, Dambrine E, Pollier B, Atteia O (2000) A comparison between $\mathrm{Ca}$ and $\mathrm{Sr}$ cycling in forest ecosystems. Plant Soil 225:299-310

Rana BS, Singh SP, Singh RP (1989) Biomass and net primary productivity in cental Himalayan forests along an altitudinal gradient. For Ecol Manag 27:199-218

Russell WA, Papanastassiou DA (1978) Calcium isotope fractionation in ion-exchange chromatography. Anal Chem 50:1151-1154

Schmitt AD, Chabaux F, Stille P (2003) The calcium riverine and hydrothermal isotopic fluxes and the oceanic calcium mass balance. Earth Planet Sci Lett 6731:1-16

Taylor AB, Velbel MA (1991) Geochemical mass balances and weathering rates in forested watersheds of the southern Blue Ridge II. Effects of botanical uptake terms. Geoderma 51:29-50

Tipper ET, Galy A, Bickle MJ (2006) Riverine evidence for a fractionated reservoir of $\mathrm{Ca}$ and $\mathrm{Mg}$ on the continents: implications for the oceanic Ca cycle. Earth Planet Sci Lett 247:267-279

Tipper ET, Galy A, Bickle MJ (2008) Calcium and magnesium isotope systematics in rivers draining the Himalaya-Tibetan-Plateau region: lithological or fractionation control. Geochim Cosmochim Acta 72:1057-1075

Vande Geijn SC, Petit CM (1979) Transport of divalent cations: Cation exchange capacity of intact xylem vessels. Plant Physiol 64:954-958

Viers J, Oliva P, Nonell A, Gélabert A, Sonke JE, Freydier R, Gainville R, Dupré B (2007) Evidence of $\mathrm{Zn}$ isotopic fractionation in a soil-plant system of a pristine tropical watershed (Nsimi, Cameroon). Chem Geol 239:124-137

White PJ, Broadley MR (2003) Calcium in plants. Ann Bot 92:487-511

Wiegand BA, Chadwick OA, Vitousek PM, Wooden JL (2005) $\mathrm{Ca}$ cycling and isotopic fluxes in forested ecosystems in Hawaii. Geophys Res Lett 32:L11404

Wong A, Howes AP, Dupree R, Smith ME (2006) Natural abundance ${ }^{43} \mathrm{Ca}$ NMR study of calcium-containing organic solids: a model study for Ca-binding biomaterials. Chem Phys Lett 427:201-205

WRB (2006) World Reference Base for Soil Resources 2006-a framework for international classification, correlation and communication. 103, Food and Agriculture Organization of the United Nations, Rome, Italy 